\title{
0-3 éves korú csecsemők és kisdedek táplálkozási szokásainak felmérése, különös tekintettel a makro- és mikronutriens-bevitelre
}

\author{
Erdélyi-Sipos Alíz ${ }^{1}$ Badacsonyiné dr. Kassai Krisztina ${ }^{1}$ - Kubányi Jolán ${ }^{1}$ \\ Szǘcs Zsuzsanna ${ }^{1}$ - Biró Lajos dr. ${ }^{2}$ - Raposa L. Bence dr. ${ }^{3}$ \\ ${ }^{1}$ Magyar Dietetikusok Országos Szövetsége, Budapest \\ ${ }^{2}$ NutriComp Bt., Budapest \\ ${ }^{3}$ Pécsi Tudományegyetem, Egészségtudományi Kar, Ápolástudományi, \\ Alapozó Egészségtudományi és Védőnői Intézet, Pécs
}

\begin{abstract}
Bevezetés: Az elmúlt időszakban megjelent kutatási eredmények alátámasztják azt a feltételezést, hogy a felnőttkori krónikus betegségek kialakulását jelentősen befolyásolja a méhen belüli tápanyag-ellátottság és a kisdedkorban folytatott táplálás és táplálkozás.

Célkituzés: A vizsgálat célja a hazai 0-3 éves csecsemők, kisdedek táplálkozási szokásainak felmérése, illetve a csecsemő- és kisdedkorú gyermekek táplálkozását a leginkább jellemző problémák feltárása, a táplálási/táplálkozási ajánlások módosításához, korszerúsítéséhez szükséges adatok megismerése, szolgáltatása volt.

Módszer: A vizsgálat a Magyar Dietetikusok Országos Szövetségének szakmai koordinálásával, iparági kutatás keretében valósult meg 2015. június és augusztus között, Budapest, Debrecen, Győr, Szeged és Pécs városainak 0-3 éves populációja körében. A felmérés antropometriai mérésekkel és validált háromnapos táplálkozási naplóval történt.

Eredmények: A 4-12 hónapos $(\mathrm{n}=220)$ csecsemók 18,6\%-a 10 percentilis alatti értékkel rendelkezett, 10\% 85-97 percentilis közé esett, míg 3\% meghaladta a 97 percentilist. A 12-24 hónapos ( $\mathrm{n}=227)$ gyermekek $15 \%$-a 10 percentilis alatti testtömegindexszel (BMI) rendelkezett (sovány), 14\% BMI-je 85-97 percentilis közé esett (túlsúlyos), és 2,6\% a 97 percentilist meghaladó BMI-vel rendelkezett (elhízott). A 25-36 hónapos gyermekek $(\mathrm{n}=184) 70 \%$-ának normál-BMI-je volt, 4\%-uk túlsúlyos, 2\%-uk elhízott, 24\%-uk sovány volt. Míg a hazai referenciaérték alapján a felmérésben részt vevő 4-12 hónapos gyerekek 10,9\%-a, az 1-2 évesek 20\%-a, a 2-3 évesek 47\%-a a magas fehérjebeviteli tartományba esett, addig a 2013-ban kiadott EFSA- (Európai Élelmiszerbiztonsági Hatóság) ajánlás referenciaértékeihez viszonyítva viszont a vizsgált gyerekek 100\%-a a magas fehérjebeviteli csoportba tartozik minden korcsoportban.

Következtetés: Bár a makro- és mikronutrienseknek a WHO/FAO/UNU által 2007-ben megadott beviteli értékein alapuló, 2013-as EFSA-ajánlás meghatározza az ajánlott beviteli mennyiségeket, a mintában felmért eredmények annak teljes körú megbízhatóságát nem támasztották alá.

Orv Hetil. 2019; 160(50): 1990-1998.
\end{abstract}

Kulcsszavak: csecsemő, táplálkozás, gyermek, fehérjebevitel, testtömegindex

\section{Nutrition assessment of $0-3$-year-old infants and toddlers with particular focus on macro- and micronutrient intake}

\footnotetext{
Introduction: Recent research findings support the assumption that the development of chronic diseases in adults is greatly influenced by the supply of nutrients in the uterus and the nutrition, nourishment of the early, toddler ages. Aim: The aim of the present study was to evaluate the nutritional habits of infants and toddlers aged $0-3$ in Hungary, and to identify the most typical problems of their nutrition, to get to know and provide the necessary data for the modification and modernization of feeding/nutrition recommendations for infants and young children in Hungary. Method: The study was carried out with the professional coordination of the Hungarian Dietetic Association (MDOSZ) in the framework of industry research between June and August 2015, in the 0-3-year-old population, in
} 
the cities Budapest, Debrecen, Győr, Szeged and Pécs. The survey was conducted with anthropometric measurements and validated by three-day dietary log templates.

Results: $18.6 \%$ of infants aged 4 to 12 months $(\mathrm{n}=220)$ had values below 10 th percentile, $10 \%$ were between $85-$ 97th percentiles and $3 \%$ were above 97 th percentile. $15 \%$ of children aged $12-24$ months $(n=227)$ had a body mass index (BMI) below 10th percentile (underweight), 14\% were between 85-97th percentile (overweight) and 2.6\% had BMI over the 97 th percentile (obese). $70 \%$ of $25-36$-month-old children $(\mathrm{n}=184$ ) had normal BMI, $4 \%$ were overweight, $2 \%$ obese, $24 \%$ underweight. Based on the Hungarian reference value, $10.9 \%$ of the $4-12$-month-old children, $20 \%$ of the $1-2$-year-olds, $47 \%$ of the $2-3$-year-olds were in high protein intake group. However, compared to the 2013's reference values of the EFSA (European Food Safety Authority) recommendation, 100\% of the children belong to the high protein intake group in all age groups.

Conclusion: Although the EFSA recommendation - based on the WHO/FAO/UNU macro- and micronutrient intake values in 2007 - defines the recommended intake quantities, the results in the sample did not support its overall reliability.

Keywords: infant, nutrition, child, protein intake, body mass index

Erdélyi-Sipos A, Badacsonyiné Kassai K, Kubányi J, Szűcs Zs, Biró L, Raposa LB. [Nutrition assessment of 0-3-yearold infants and toddlers with particular focus on macro- and micronutrient intake]. Orv Hetil. 2019; 160(50): 1990-1998.

(Beérkezett: 2019. július 18.; elfogadva: 2019. augusztus 20.)

\begin{abstract}
Rövidítések
$\mathrm{BMI}=($ body mass index $)$ testtömegindex; EFSA $=($ European Food Safety Authority) Európai Élelmiszerbiztonsági Hatóság; $\mathrm{FAO}=($ Food and Agriculture Organization of the United Nations) Élelmezésügyi és Mezőgazdasági Világszervezet; ICP = (infancy childhood puberty) csecsemö-, gyermek-, serdülőkori modell; IGFl = (insulin-like growth factor 1$)$ inzulinszerü növekedési faktor- $1 ;$ RÉ $=$ referenciaérték; TGI = (Target Group Index) Célcsoport Index; UNU = (United Nations University) Egyesült Nemzetek Egyeteme; UVB = (ultraviolet B) ibolyántúli B, közepes hullámhosszú sugárzás; WHO = (World Health Organization) Egészségügyi Világszervezet
\end{abstract}

Az étrend minősége minden életszakaszban meghatározó eleme az egyén egészségi állapotának. Szerepe a krónikus, nem fertőző betegségek kialakulásában ma már kellően bizonyított, éppen ezért a táplálkozás területén megvalósított intervenció nélkülözhetetlen eleme a prevenciónak. A krónikus betegségek előfordulása napjainkban világszerte egyre szélesebb tömegeket érint. Ma már azt is tudjuk, hogy ezen kórállapotok többsége ugyanazon kockázati tényezókre, köztük a helytelen táplálkozásra vezethető vissza. Felmerül ugyanakkor, ha a megbetegedések önmagukban nem fertőzőek is, mégis annak tekinthetők a kockázati tényezők szintjén, hiszen az életmódszokások öröklődnek egyik generációról, populációról a másikra, illetve a globalizációnak köszönhetően sokszor az országhatárokat is átlépik [1-3].

Szintén bizonyítottnak tekinthető, hogy a krónikus megbetegedések rizikója már a magzati életben megjelenik és az időskorig elkíséri az egyént. Ennélfogva a felnőttkorban manifesztálódó betegségek az egész életen át tartó környezeti hatások (fizikai és szociális), valamint életmódszokások (például táplálkozás) halmazati követ- kezményének tekinthetók. Az említett jelenség ugyanakkor bármely életkorban számos lehetőséget ad a beavatkozásra $[4,5]$.

A gyermek születési testtömege, illetve hossza meghatározó nemcsak a pillanatnyi morbiditás, mortalitás szempontjából, de hosszú távon is befolyásolja az egészségügyi kilátásokat. Példaként említhető az intrauterin növekedés elmaradása (kis súlyú magzat) és a szívkoszorúér-betegségek, a stroke, a diabetes és a magas vérnyomás magasabb rizikója közötti összefüggés. Ugyanígy a magas születési testtömeg (ún. macrosomia), valamint a diabetes, illetve a szív- és érrendszeri betegségek, az emlő- és egyéb daganatok emelkedett kockázata közötti korreláció is megfigyelhető [6-11]. A felnőttkori krónikus betegségek kialakulását igen jelentősen befolyásolja az élet fogantatástól számított első 1000 nap időszakában a táplálás módja, annak mennyisége és minősége [12]. Ennek ismeretében a táplálás kiemelt jelentőséggel kezelendő már a magzati élet kezdetétől. A tudományos figyelem korábban a méhen belüli alultápláltság és a csökkent születési testtömeg káros hatásaira irányult. Az elhízás járványszerű terjedésével azonban napjainkban egyre inkább a várandósság és a szoptatás alatt bekövetkező anyai túltáplálkozásnak az utód hosszú távú egészségi állapotát érintő hatására tevődik át a hangsúly [13].

A kora csecsemőkori élet környezetének jelentősége is egyre jobban felértékelődik, hiszen a korai gyors súlygyarapodáshoz későbbi elhízás társulhat, a méhen belüli gyarapodástól függetlenül. A megfigyeléseken alapuló tanulmányok után most ennek a területnek a kutatása a programozás hátterében álló molekuláris mechanizmusok jobb megismerésére törekszik $[14,15]$. Többek között ezért is kiemelt jelentőségű a csecsemőtáplálás. Az 1980-as években Karlberg az emberi növekedés modulátorainak modelljét terjesztette elö, a csecsemő-, gyer- 
mek-, serdülőkori modellt (infancy childhood puberty, ICP). Meglátása szerint a gyermek növekedése három jól elkülöníthető szakaszban zajlik, melyek folyamán három szabályozó tényező egymást átfedő hatásokat fejt ki. Gyermekkorban a növekedést a növekedési hormon szabályozza, melynek hatását az inzulinszerú növekedési faktor, az IGFl termelése közvetíti. A serdülőkori növekedési megugrást a nemi hormonok hozzátevődő anabolikus hatása okozza. A csecsemőkori gyors növekedést ezzel ellentétben azoknak a tápanyagoknak a bevitele serkenti, amelyek a növekedési faktor, az inzulin és az IGFl termelését stimulálják. Ez lehet a magyarázata annak, hogy az anyatejjel táplált csecsemőkhöz viszonyítva a tápszerrel tápláltaknál elő́lló magasabb fehérjebevitel megemelheti a vérplazmában és a szövetekben az inzulin- és IGFl-szintet, ilyen módon fokozva a korai súlygyarapodást és később az elhízást [16]. A csecsemő́k fehérjebevitelével foglalkozó kutatás és klinikai érdeklődés középpontjában korábban a hiány kockázatai, ezek megelőzése és kezelése állt. Mivel a szükséglettól elmaradó fehérjebevitel egyértelmúen károsan érinti a növekedést, fejlődést, csecsemőkorban hagyományosan bőséges fehérjebevitelt szorgalmaznak [17]. A koraifehérje-hipotézis azonban, vagyis annak a feltevésnek a tudományos megfogalmazása, miszerint az első életévben nyújtott feleslegesen nagy fehérjebevitelhez a csecsemő gyors súlygyarapodása társul, ami a későbbi életkorokban az elhízás és a vele rokon állapotok kockázatának növekedésével is jár, ezt az irányvonalat kérdőjelezi meg [18, 19]. Ezen folyamat legjobb megelőzési eszköze az anyatejes táplálás, hisz tudjuk, hogy az anyatejjel táplált csecsemók körében a túlsúly vagy elhízás előfordulása alacsonyabb, mint tápszeres társaiknál. Amennyiben nem lehetséges a szoptatás, vagy nem áll rendelkezésre elegendő anyatej, akkor viszont kiemelt jelentőségú, hogy az anyatej fehérje-összetételéhez legközelebb álló tápszerrel történjen a táplálás [20].

\section{Módszer}

A nagyvárosi reprezentativitás biztosítása érdekében több területről (Budapest, Debrecen, Szeged, Pécs, Győr) kerültek bevonásra résztvevoók a mintába. A mintavétel alapját egyrészről a TNS Hofmann Kft. által biztosított Target Group Index (TGI) nagymintás kutatása, másrészről a célzott adatfelvétel adta. A reprezentativitás biztosítása érdekében a TGI kutatási mintájából meghatározásra került a célcsoport nagysága, valamint a minta demográfiai háttere, összetétele (korcsoport, lakóhely, iskolai végzettség) egyaránt. A vizsgálatban részt vevő édesanyák megkeresése kérdezőbiztos által történt, véletlenszerü, random mintaválasztással és „,snow-balling” módszerrel 2015. június és augusztus között. Kizárási kritérium: az önkéntesség feltételén kívül, a normál, szájon át való táplálást akadályozó betegség, valamint a lázas állapot, fertőző betegség. A validált kérdőívek, táplálkozási naplók adatainak statisztikai feldolgozását az
Excel 2016 (Microsoft Corporation, Redmond, WA, Amerikai Egyesült Államok [USA]), valamint az SPSS 24.0 (IBM Corporation, Armonk, NY, USA) programokkal végeztük el.

Kutatásunkban feldolgozásra kerültek az egészséges, időre született, 0-6 hónapos, nem kizárólag anyatejjel táplált (anyatej, anyatej és/vagy tápszer) csecsemóknek ( $\mathrm{n}=97)$, a 4-12 hónapos, a hozzátáplálást megkezdett csecsemóknek $(\mathrm{n}=220)$ és a 12-36 hónapos kisdedeknek $(\mathrm{n}=41 \mathrm{l})$ a táplálkozására, tápláltságára vonatkozó adatok egyaránt. A kérdőívek $(\mathrm{n}=728)$ 1,2\%-a kizárásra került azonosítási problémák, valamint a szélsőségesen csekély vagy nagy energiafelvétel miatt, biztosítva ezzel a szélsőértékek kizárását. A jelen cikkben a 0-6 hónapos korosztályra vonatkozó mérési eredményeket nem mutatjuk be, a kizárólagos anyatejes táplálás preferálása miatt.

A felmérés „háromnapos táplálkozási napló” és kérdőív segítségével történt, a nemzetközi ajánlásnak megfelelóen, majd a visszakérdezett és pontosított adatokat dietetikus szakemberek rögzítették a „NutriComp Étrend” szoftverben, amellyel energiatartalom- és tápanyagszámítás történt.

Az energia- és tápanyagfelvételi adatokat a hazai ajánlások referenciaértékei (RÉ) alapján kategóriákba soroltuk (kritikus határérték alatti - a RÉ <70\%-a; megfelelő felvétel - a RÉ 70-130\%-a; határérték feletti - a RÉ $>130 \%$-a ), majd összehasonlítottuk. A szoftver adatbázisa lehetővé tette a speciális elemzéseket, mivel a korcsoport-specifikus, csecsemők és kisgyermekek számára készített élelmiszereket, ételeket, valamint az esetlegesen alkalmazott étrend-kiegészítőket is tartalmazta.

A kutatásban részt vevő gyermekek antropometriai paraméterei - mint a testtömeg, a testhossz és a testmagasság - validált múszerekkel kerültek felmérésre. A mért adatokból testtömegindexet (BMI) számoltunk, majd a Cole-féle módszer alapján kategóriákat alkottunk; s mivel a gyermekek kétéves kora alatt nem áll rendelkezésre megbízható BMI-határérték-táblázat, szükségszerúen a hazai BMI-percentilis-táblázatok határértékei alapján meghatározott kategóriák kerültek kialakításra [21-24].

\section{Eredmények}

\section{Tápláltsági állapot, energiabevitel}

Az összes energiabevitelt megvizsgálva elmondható, hogy a 4-12 hónapos korcsoport fele a határérték feletti, magas energiabevitellel rendelkezik. Ez az arány az l-2 évesek körében közel 85\%, míg a 2-3 éves kisdedek esetében megközelíti a 76\%-ot. A kutatásban felmért 4-36 hónapos korosztály energiabeviteli adatainak megoszlását az 1 . ábra szemlélteti.

Megemlítendő továbbá, hogy az energiabeviteli adatok mellett a testtömegadatok kiértékelésekor is körültekintésre volt szükség. Az adatok helyes interpretációjá- 


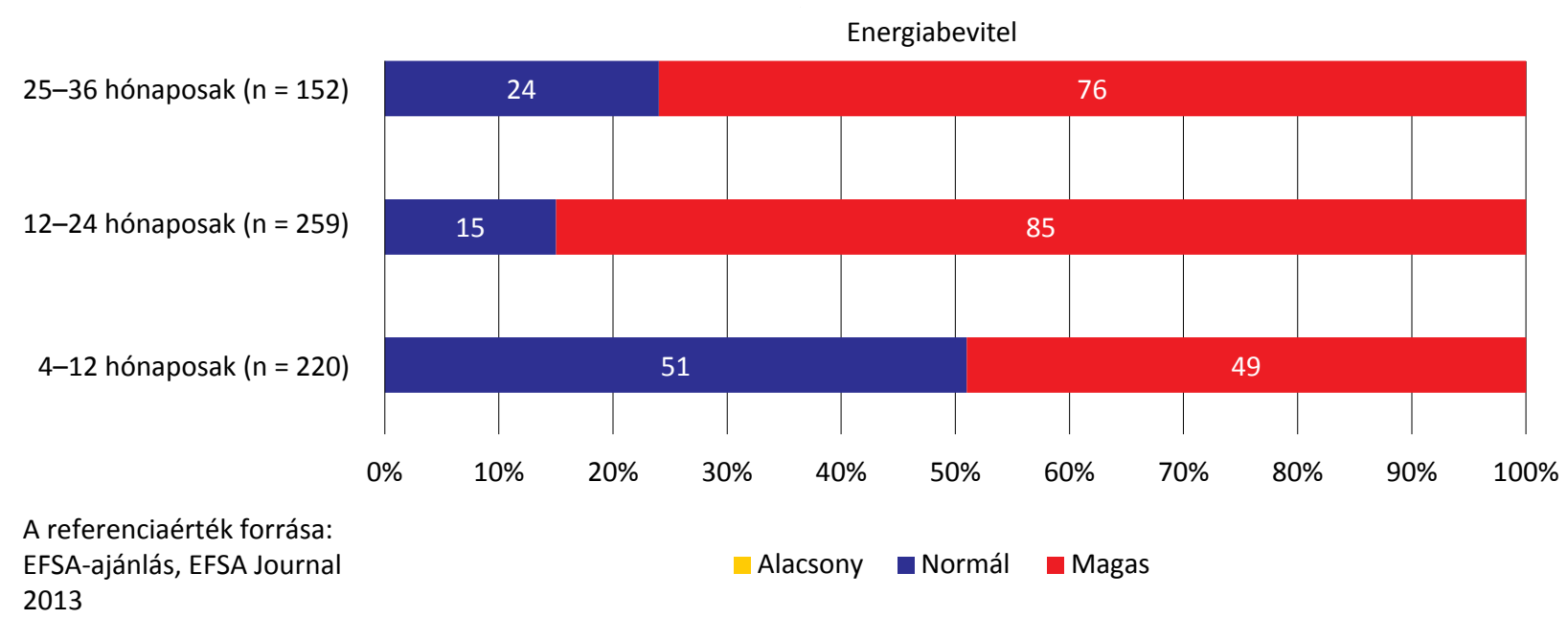

1. ábra A 4-36 hónapos korcsoport napi energiabevitele a referencia-beviteliérték arányában

hoz a hazai és a nemzetközi ajánlások felnőttkori BMI-táblázatai mellett figyelembe kellett vennünk és mérlegelnünk a vizsgált csoportok egyedi sajátosságait is. Ennek ismeretében elmondható, hogy a túlsúly és az elhízás a 2-3 éves korosztály 6,5\%-át érintette. A mért adatokat az 1. táblázat prezentálja.

1. táblázat |A 4-36 hónapos korosztály tápláltsági állapota

\begin{tabular}{|c|c|c|c|c|c|}
\hline \multicolumn{6}{|c|}{ Hazai percentilisértékek, kategóriák } \\
\hline & $\begin{array}{c}\text { BMI-átlag } \\
\left(\mathrm{kg} / \mathrm{m}^{2}\right)\end{array}$ & $<10 \mathrm{pct}$ & $10-84,9 \mathrm{pc}$ & $85-96,9 \mathrm{pct}$ & $\geq 97 \mathrm{pct}$ \\
\hline 4-12 hó & 16,5 & 18,6 & 68,2 & 10,0 & 3,2 \\
\hline 12-24 hó & 16,5 & 15,0 & 68,3 & 14,1 & 2,6 \\
\hline \multicolumn{6}{|c|}{ Cole-kategóriák } \\
\hline & & „Sovány” & „Normál” & „Túlsúlyos” & „Elhízott” \\
\hline 25-36 hó & 15,8 & 23,9 & 69,6 & 4,3 & 2,2 \\
\hline
\end{tabular}

A hazai BMI-percentilis-táblázatok alapján (korcsoportok szerint szeparálva) a kétéves vagy annál fiatalabb gyermekek 15-18,6\%-a 10 percentilis alatti BMI-vel ren- delkezik, potenciálisan sovány, 10-14,1\%-uk potenciálisan túlsúlyos (BMI: 85-97 percentilis), 2,6-3,5\%-uk potenciálisan elhízott (BMI >97 percentilis) (1. táblázat) [23].

Ezen adatok ismeretében fontos felhívnunk a szakemberek és a lakosság figyelmét, hogy egészséges gyermekek esetében az első két évben (0-24 hó) nem kívánatos a gyors testtömeg-gyarapodás. A percentilisek határán elhelyezkedő BMI pedig célzott beavatkozást igényel [25].

\section{Makro-és mikroelemek (vitaminok, egyéb tápanyagok)}

\section{Fehérjebevitel}

A testtömegkilogrammra meghatározott fehérjebevitel a 4-12 hónaposak esetében $3,1 \mathrm{~g} / \mathrm{ttkg}$ (EFSA-ajánlás: 1,48-1,65 g/ttkg), míg a 12-36 hónapos gyermekeké 4,1 g/ttkg (EFSA-ajánlás: 1,13-1,26 g/ttkg) volt. Félegy éves kor körüli időszaktól kezdődően a gyermekek fehérjebevitele jelentősen meghaladja a testtömegarányos ajánlásokat. A mért fehérjebeviteli értékeket a 2. ábra mutatja be.

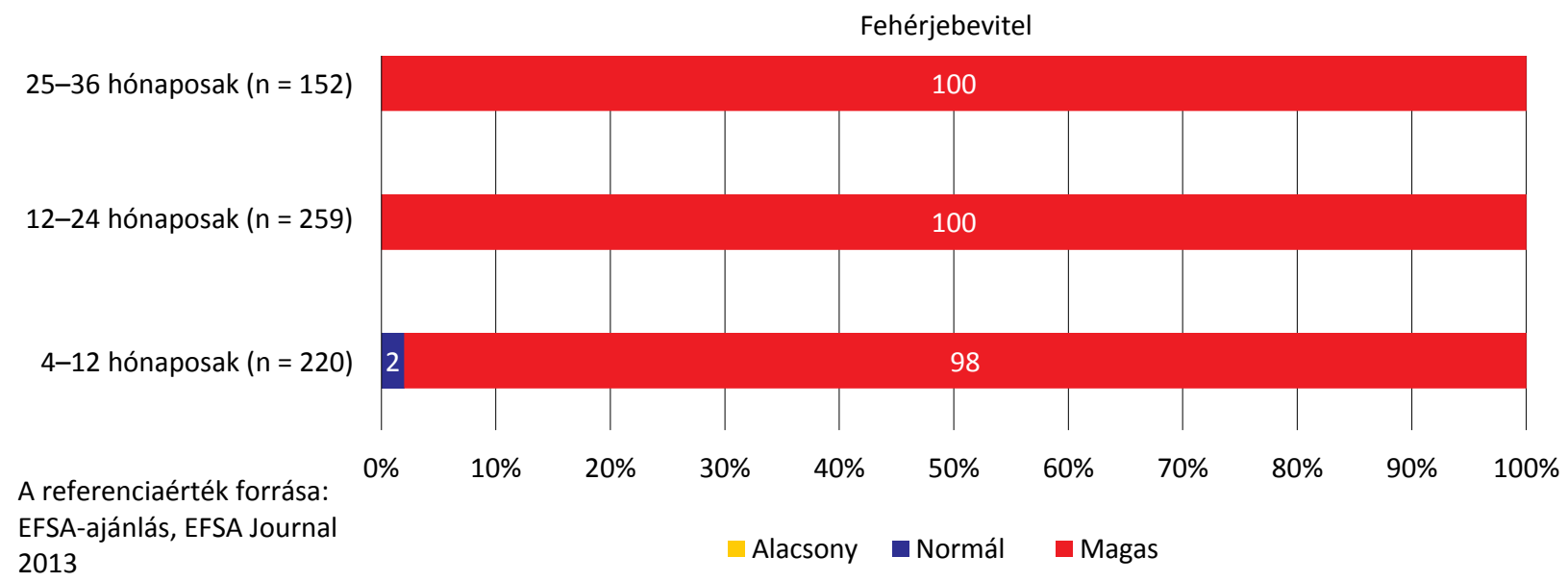

2. ábra | A 4-36 hónapos korcsoport fehérjebevitele 


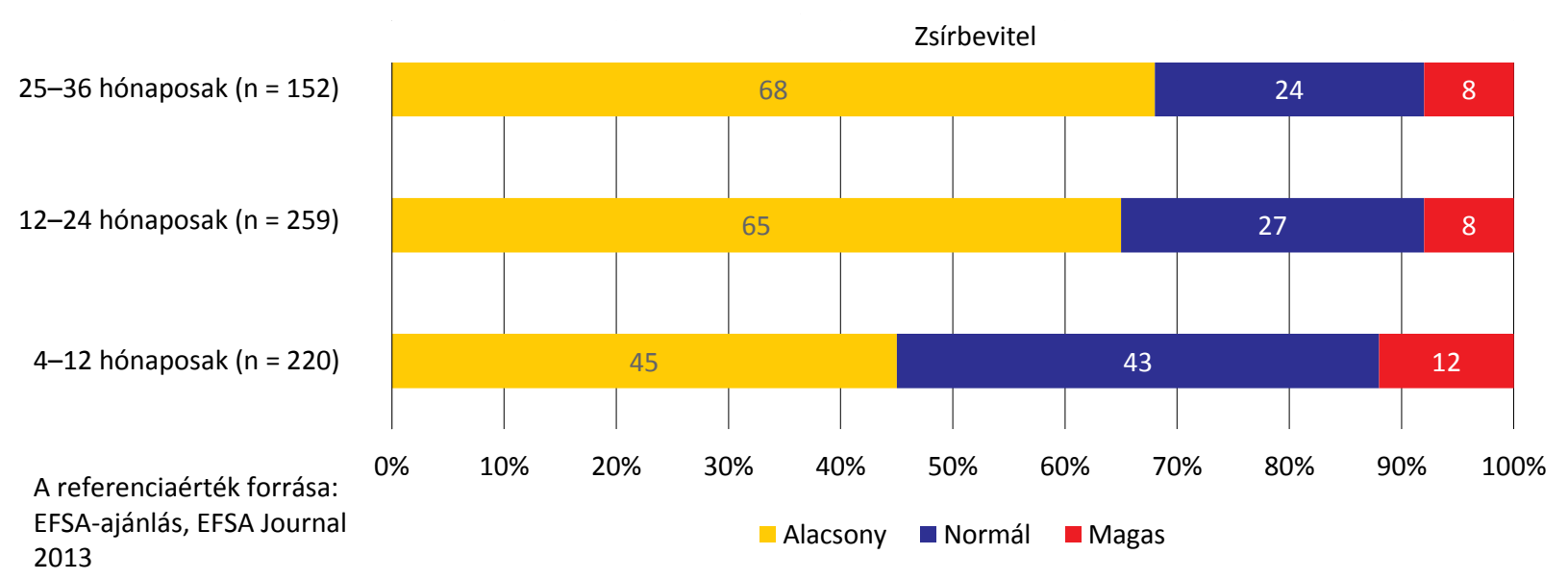

3. ábra $\quad$ A 4-36 hónapos korcsoport zsírbevitele

\section{Zsírbevitel}

A zsírok felvételének tekintetében e korcsoportban kevésbé jellemző a határérték feletti bevitel. A 4-12 hónaposak 43\%-ának, az 1-2 évesek 27\%-ának és a 2-3 éves kisdedek 24\%-ának megfelelő a zsírbevitele. Az alacsony zsírfogyasztás a leginkább az 1 éves feletti korcsoportot jellemzi (12-24 hónaposak: 65\%, 25-36 hónaposak: 68\%) (3. ábra). Amennyiben a hazai referenciaérték-tartományhoz (Rodler Imre [szerk.] Új tápanyagtáblázat) viszonyítjuk, akkor nagyobb százalékban szerepelnek a csecsemők és a kisdedek a normáltartományban, és kevesebb az alacsony zsírbevitelúek aránya. Az egyes tápanyagok élelmiszercsoportonként való megoszlásának (százalékos tápanyagprofil) közvetlen elemzésére nem volt lehetőség, azonban vizsgálható az egyes tápanyagok bevitele és az élelmiszercsoportok fogyasztásának összefüggése. A 4-12 hónapos gyermekek $(n=220)$ napi átlagos zsírfogyasztása 30,6 g/fó, amelyből állati eredetű 14,6 g, növényi eredetü 6,7 g. 12-24 hónaposaknál $(\mathrm{n}=259)$ a napi zsírfogyasztáson $(45,9 \mathrm{~g})$ belül ez az arány $25,3 \mathrm{~g}$ és 16,6 g, 25-36 hónapos korban $(\mathrm{n}=152)$ a napi 53,9 g zsírbevitelből 30,5 g állati eredetü, míg 22,7 g növényi.
A 4-12 hónapos (hozzátáplált) csecsemők jelentős hányada kedvezőtlenül magas bevitelt mutat koleszterin (40,9\%) esetén. Ez igaz az 1-3 éves gyermekek felére is $(50,1 \%)$. A koleszterinbevitel szempontjából pozitív öszszefüggés van a tejek, tejtermékek, tojás, húsok, majd a hús- és májkészítmények esetében.

\section{Szénhidrát és hozzáadott cukor bevitele}

A 4-12 hónapos korcsoport közel felének határérték feletti, míg az 1-3 évesek többségének megfelelő (12-24 hónaposak: 77\%, 25-36 hónaposak: 82\%) a szénhidrátbevitele (4. ábra).

A hozzáadott cukor 4-12 hónapos korban fordított összefüggést mutat a tej és tejtermékek fogyasztásával, pozitív összefüggést pedig a kész és félkész ételek, bébiételek fogyasztásával. A hozzáadott cukor napi bevitele a 4-12 hónapos korcsoportban 11,5 g, az 1-2 éveseké $27,5 \mathrm{~g}$, és a 2-3 éveseké 45,3 g. A szénhidrátokon belül a hozzáadott cukorból származó energia a 12-36 hónapos gyermekek esetében közel 10\%, csecsemők esetén 3-5\% körüli.
Szénhidrátbevitel

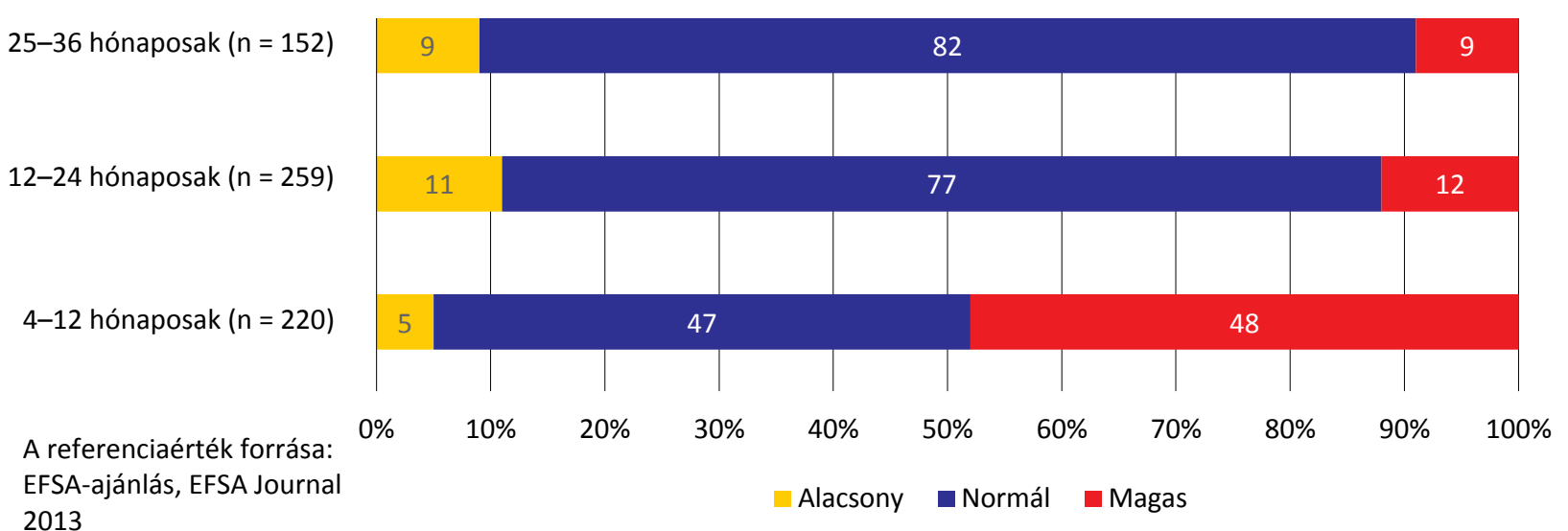

4. ábra | A 4-36 hónapos korcsoport napi szénhidrátbevitele 
2. táblázat Ásványi anyagok átlagos napi bevitele (4-36 hónapos gyermekek körében)

\begin{tabular}{lccccc}
\hline $\begin{array}{l}\text { Korcsoport } \\
(\text { hó })\end{array}$ & $\begin{array}{c}\text { Nátrium } \\
(\mathrm{mg})\end{array}$ & $\begin{array}{c}\text { Kálium } \\
(\mathrm{mg})\end{array}$ & $\begin{array}{c}\text { Kalcium } \\
(\mathrm{mg})\end{array}$ & $\begin{array}{c}\text { Magnézium } \\
(\mathrm{mg})\end{array}$ & $\begin{array}{c}\text { Vas } \\
(\mathrm{mg})\end{array}$ \\
\hline $\begin{array}{l}4-12 \\
(\mathrm{n}=220)\end{array}$ & 623 & 1378,7 & 465,7 & 128,71 & 6 \\
$\begin{array}{l}12-36 \\
(\mathrm{n}=411)\end{array}$ & 1236 & 1949,9 & 632,57 & 228,62 & 7,4 \\
$\begin{array}{l}12-24 \\
(\mathrm{n}=259)\end{array}$ & 1704 & 1823,4 & 590,2 & 210,1 & 7,19 \\
$\begin{array}{l}25-36 \\
(\mathrm{n}=152)\end{array}$ & 2198,5 & 2165,4 & 704,6 & 260 & 7,76 \\
\hline
\end{tabular}

\section{Ásványi anyagok és vitaminok bevitele}

A 4-12 hónapos (hozzátáplált) csecsemők jelentős hányadának (71\%) kedvezőtlenül magas a nátriumbevitele, míg az egyéb ásványi anyagok és vitaminok többségének felvétele jónak mondható; ugyanakkor fontos megemlíteni a jelentős prevalenciájú $(22,1 \%)$ elégtelen kalciumfelvételt, valamint a nagyarányú vas- (43\%) és D-vitaminhiányt (79\%). Az 1-3 éves gyermekek száz százaléka magas bevitelt mutat a nátrium esetén, és foszforból ez az arány $67 \%$; hiányosnak tekinthetô a kalcium $(41,8 \%)$, a vas $(25 \%)$ és a $\mathrm{D}$-vitamin $(87,1 \%)$ bevitele. E korcsoport kevésbé használ D-vitaminos étrend-kiegészítőt, így étrend-kiegészítővel ez az arány csak 65\%-ra csökken. A korcsoportokra lebontott ásványianyag-bevitelek átlagát a 2. táblázat tartalmazza.

A többlet-nátriumbevitel a 4-12 hónapos és az 1-3 éves korcsoportban elsősorban a kenyérfélék, a húskészítmények és az ízesítőanyagok, füszerek, egyéb élelmiszercsoportok fogyasztásából származik. Az ételkészítési szokásokkal és az élelmiszer-választásban megfigyelhető sajátosságokkal magyarázható a kedvezőtlenül magas nátriumbevitel.

A vas nélkülözhetetlen a pszichomotoros és kognitív funkciók fejlődéséhez, hiányában ezekben a funkciókban zavarok keletkezhetnek. A kor előrehaladtával javuló tendenciát mutat az elégtelen vasbevitel, hiszen a 4-12 hónapos (hozzátáplált) csecsemőknél talált nagyarányú vashiány 42,3\%-ról 1-3 éves gyermekeknél 25,3\%-ra csökkent. Fontos kiemelni, hogy megfelelő hozzátáplálással, étkeztetéssel ezek az arányok jelentősen javíthatók lennének. A 4-12 hónapos csecsemők 70\%-a kap húst és húskészítményt (átlagosan 33,6 g/fö/nap) és 18\%-uk belsőséget (átlagosan 9,1 g/fö/nap). A 12-36 hónaposak 99\%-a fogyaszt húst és húskészítményeket (átlagosan 71,2 g/fö/nap), 33\%-uk belsőséget (átlagosan 9,7 g/ fö/nap).

A kalciumbevitel a 4-12 hónapos (hozzátáplált) csecsemők 22,1\%-ánál és az 1-3 éves gyermekek 41,8\%ánál hiányosnak tekinthető. Az életkor növekedésével jelentősen nő az alacsony kalciumbevitellel rendelkezők száma. A 4-12 hónapos csecsemők 79\%-a kap tejet és tejterméket (átlagosan 362,1 g/fó/nap). A 12-36 hónaposak 100\%-a kap ebból az élelmiszercsoportból (átlagosan 320,7 g/fö/nap), vagyis az életkor elörehaladtával csökken a tej és tejtermékek fogyasztásának mennyisége. Az eredményt tovább rontja, hogy az 1-3 éves korosztály 31,6\%-a kedvezőtlenül magas bevitelt mutat a foszfor tekintetében, így még inkább eltolódik az ajánlott 1,4: 1 - 1,9: 1 kalcium : foszfor arány. Ez az intenzív csontfejlődés szakaszában igen nagy problémát jelent. Az adatok a későbbi életkorban sem alakulnak kedvezően [26].

\section{Vitaminok bevitele}

A tudományos publikáció formai követelményei nem teszik lehetôvé a teljes vizsgálati anyag részletes ismertetését, ugyanakkor az egyik legfontosabb vitamin beviteli értékei mellett nem mehetünk el szó nélkül, annak korcsoport-specifikus fontossága miatt.

A D-vitamin-bevitel az elvárt szintnél alacsonyabb értékeket mutatott mind a 12-24 hónapos kisdedek (83\%), mind a 25-36 hónapos gyermekek esetében (94\%). Étrend-kiegészítőket is figyelembe véve ezek az értékek 58\%-ra, illetve 76\%-ra csökkentek. A táplálkozási naplók elemzésekor az érintettek táplálékkal, illetve étrend-kiegészítővel történő $\mathrm{D}$-vitamin-felvételének vizsgálatára volt elsősorban lehetőségünk. Ugyanakkor a vizsgálat során kitöltött kérdőívből kiderült, hogy a gyermek növekedésével egyenes arányban nő a szabad levegőn töltött idő hossza. Az 1 éves kor alatti gyermekekkel tipikusan 1-2 órát, míg az idősebbekkel a legtöbben 2-4 órát töltenek a szabadban. Ez a bőrt érő napsugárzásnak, illetve a napsugarak UVB-spektrumának az endogén-Dvitamin-szintézisben betöltött szerepe miatt nagy jelentôségü [27].

A felmért, részletes vitaminbeviteli átlagokat a 3. táblázat tartalmazza.

3. táblázat |Vitaminok átlagos napi bevitele (4-36 hónapos gyermekek körében)

\begin{tabular}{|c|c|c|c|c|c|c|c|c|c|}
\hline $\begin{array}{l}\text { Korcsoport } \\
\text { (hó) }\end{array}$ & $\begin{array}{c}\text { A-vitamin } \\
(\mu g)\end{array}$ & $\begin{array}{c}\beta \text {-Karotin } \\
(\mathrm{mg})\end{array}$ & $\begin{array}{c}\mathrm{B}_{1} \text {-vitamin } \\
(\mu \mathrm{g})\end{array}$ & $\begin{array}{c}\text { B }_{2} \text {-vitamin } \\
(\mu g)\end{array}$ & $\begin{array}{c}\text { B }_{6} \text {-vitamin } \\
(\mu \mathrm{g})\end{array}$ & $\begin{array}{c}\mathrm{B}_{12} \text {-vitamin } \\
(\mu \mathrm{g})\end{array}$ & $\begin{array}{l}\text { C-vitamin } \\
\text { (mg) }\end{array}$ & $\begin{array}{c}\text { D-vitamin } \\
(\mu \mathrm{g})\end{array}$ & $\begin{array}{c}\text { Folsav } \\
(\mu \mathrm{g})\end{array}$ \\
\hline $4-12(n=220)$ & 574,8 & 3,76 & 643,15 & 682,7 & 775,4 & 1,19 & 80,8 & 4,35 & 72,8 \\
\hline $12-36(n=411)$ & 419,9 & 2,47 & 726 & 1020,9 & 1115,5 & 2,51 & 86,37 & 3,36 & 109,1 \\
\hline $12-24(\mathrm{n}=259)$ & 435,3 & 2,53 & 711,9 & 947,76 & 1048,7 & 2,00 & 78,9 & 3,93 & 102,4 \\
\hline $25-36(n=152)$ & 393,6 & 2,37 & 750,2 & 1145,7 & 1229,4 & 3,31 & 99 & 2,4 & 120,5 \\
\hline
\end{tabular}




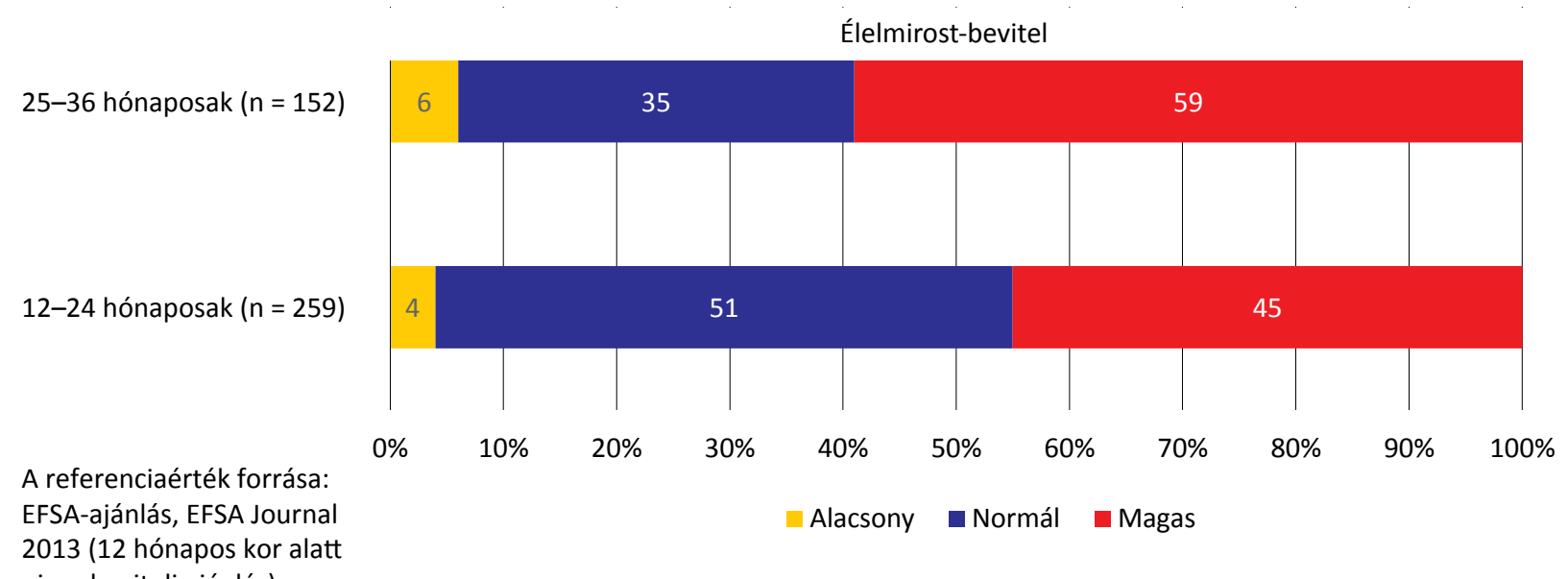

nincs beviteli ajánlás)

5. ábra

| A 12-36 hónapos korcsoport élelmirost-bevitele

\section{Egyéb tápanyagok}

Vegyes táplálkozás mellett a 12-24 hónapos korcsoport felének megfelelő az élelmirost-bevitele, csupán 4\%-uknak alacsonyabb a referenciaértékhez hasonlítva. Az 1-3 évesek 59\%-ára magasabb rostbevitel jellemző, 35\%-uk megfelelő mennyiségú élelmi rostot fogyaszt, és csak 6\%nak elégtelen az élelmirost-bevitele (5. ábra).

\section{Megbeszélés}

2015-ben végzett kutatásunk célcsoportját 0-3 éves kor közötti csecsemők és kisdedek képezték. A vizsgálati mintát önként jelentkező édesanyák és gyermekeik alkották. A csecsemő- és kisdedkorban jellemző etetési és táplálkozási szokások felmérése az esetleges intervenciók tervezése, megvalósítása szempontjából ideális időszak, mivel a helyes étkezési mintákat ekkor sajátíthatja el a gyermek, és a hibák korrekciójára még lehetősége van a családnak.

Az epigenetika, a korai anyagcsere-programozás rávilágít a legfontosabb környezeti tényezők - kiemelten a táplálkozás - hatására, a csecsemők hosszú távú egészségére vagy éppen betegségeik kialakulásának kockázatára, vagyis a csecsemő és kisded táplálása nemcsak az adott időszakban befolyásolja a gyermek fejlődését, hanem a felnőttkori nem fertőző betegségek kialakulására is hatással van [28]. A társadalom egészségfejlesztését, valamint a civilizációs betegségek prevencióját ennek okán már gyermekkorban szükséges megkezdeni, ugyanis egy 2010-ben végzett felmérés szerint a vizsgált 1-3 éves korcsoportú gyermekek táplálkozásában, illetve egy 2014-ben 4-10 éves gyermekek körében végzett vizsgálat adatainak elemzése alapján a felnőtt lakosságra is jellemző táplálkozási hibák nyomai már felfedezhetők [29, 30]. A csecsemő- vagy kisdedkorú gyermekek fejlődésük azon periódusában vannak, amikor érdemi beavatkozás tehető a kedvező táplálkozási szokások és preferenciák kialakításáért, melyek a felnőttkori egészségi állapotot is befolyásolhatják [12].
Az EFSA által meghatározott, 0-3 éves gyermekekre vonatkozó referencia-beviteliértékek szerint magas energiabevitelü a 12-24 hónapos gyermekek 84,6\%-a; 25-36 hónapos korban ez az érték 75,7\%. Míg a hazai referenciaérték alapján a felmérésben a 4-12 hónapos gyerekek 10,9\%-a, az 1-2 évesek 20\%-a, a 2-3 évesek 47\%-a a magas fehérjebeviteli tartományba esett, addig a 2013-ban kiadott - a makro- és mikronutrienseknek a WHO/ FAO/UNU által 2007-ben megadott beviteli értékein alapuló - EFSA-ajánlás referenciaértékeihez viszonyítva a vizsgált gyerekek 100\%-a a magas fehérjebeviteli csoportba tartozik minden korcsoportban [31-32]. A Magyar Gyermekorvosok Társaságának koordinálásában 2010-ben az 1-3 éves gyermekek komplex táplálkozási vizsgálata történt meg hasonló módszerekkel, igaz, kisebb elemszámmal (92 fó 1-2 éves és 102 fó 2-3 éves) [29]. Ezért a jelen vizsgálat néhány értékét összevetettük az öt évvel ezelőtt kapott adatokkal is. Az 1-3 éves gyermekek esetében az energiabevitel szempontjából jelentős különbség nincs a két vizsgálat (2010 vs. 2015) eredménye között, de a magas energiatartományba mintegy 6\%-kal több gyermek tartozik 2015-ben. A makrotápanyagok tekintetében közel megháromszorozódott a magas zsírbevitelü gyermekek aránya (8,2\% vs. 24,1\%). Vizsgálatunkban az energiát szolgáltató makrotápanyagok (zsír és szénhidrát) a 4-12 hónapos korcsoportban közel normálmegoszlást mutattak, a kor növekedésével azonban az EFSA-ajánlás szerint magas az alacsony zsírbevitellel rendelkezők aránya (mintegy 65\%) - a gyakorlatilag megfelelő, többségében normál- (mintegy 80\%) szénhidrátbevitel mellett [32]. 4-12 hónapos korban pozitív összefüggés van a BMI és a napi energiabevitel, valamint a makrotápanyagok (fehérje, zsír, szénhidrát) napi bevitt mennyisége között. Az energiamegoszláson belül a zsírból származó energiával pozitív, a szénhidrátenergia-\%-kal negatív összefüggés mutatható ki. 12-36 hónapos korban a táplálkozás szerkezetének jelentős változása, valamint a szomatikus fejlődés dinamizmusa miatt a csoport nem tekinthető homogénnek; ez megmu- 
tatkozik abban is, hogy a nagy mintaszám ellenére sem mutatható ki összefüggés a tápanyagkomponensek és a BMI között.

A mikrotápanyagok tekintetében kedvezőtlen változás következett be: nőtt az alacsony kalciumbevitelúek aránya, javult azonban a megfelelő vas- és cinkbevitelüek hányada.

A 2010-ben 1-3 éves gyerekek $(\mathrm{n}=211)$ között végzett felméréshez képest pozitívnak mondható, hogy 2015-re 10\%-kal csökkent az alacsony, 3\%-kal nőtt a normál- és 7\%-kal a magas vasbevitellel rendelkező 1-3 éves gyermekek $(\mathrm{n}=41 \mathrm{l})$ száma, de az l-3 éves korosztály 25\%-a még mindig nem jut megfelelő mennyiségű vashoz [29].

Egy 2014-ben 4-10 éves budapesti és kecskeméti gyermekekre reprezentatív táplálkozási felmérésben $(\mathrm{n}=$ 799) a kalcium átlagos napi felvétele korcsoportonként kissé változó mértékben, de szintén elmaradt az ajánlott napi $800 \mathrm{mg}$ értéktől, és a gyermekek 35\%-a kritikus, határérték alatti mennyiségben fogyasztotta ezt az ásványi anyagot. Összességében a 4-12 hónapos gyermekek 22\%-ánál, a 12-36 hónaposak 42\%-ánál volt detektálható az elégtelen kalciumbevitel. Itt is megfigyelhető, hogy a napi foszforfelvétel átlaga meghaladja az ajánlott 620 mg értéket, így kedvezőtlen a kalcium és a foszfor hányadosa is. Az elégtelen kalciumbevitelhez vezető egyik tényező, hogy a kalcium fó élelmiszerforrásául szolgáló tej és tejtermék fogyasztása a 4-6 éveseknél összességében 314 g/nap, míg a 7-10 éveseké $290 \mathrm{~g} / \mathrm{nap}, \mathrm{s}$ ez elmarad a kívánatos mintegy $450-500 \mathrm{~g} /$ nap mennyiségtől [33].

A nátriumbevitel szempontjából is aggasztóak az eredmények. Egy hazai vizsgálat megállapításai szerint 6 hónapos kor felett minden korcsoportban magasabb a nátriumbevitel: $400 \mathrm{mg}$ [34].

Vizsgálatunkban „fény derült” arra a tényre is, hogy 1 éves kor felett a gyermekek 61\%-a ugyanazt eszi, mint a család felnőtt tagjai, így a helytelen táplálkozási minta már ekkor megmutatkozik - többek között - a magasabb nátriumfogyasztásban.

A vizsgálati eredményekből látható, hogy mind a genetikai heterogenitás, mind pedig az egyes nemzetekre jellemző táplálkozás nagyban befolyásolja a beviteli referenciák alkalmazhatóságát. Tekintettel arra, hogy a tápláltsági állapotnak, valamint az egyes makro- és mikronutriensek bevitelének a megítélése kiemelten fontos ebben a korosztályban, így célszerü lenne egy hazai konszenzus megalkotása, amelynek kialakításában az összes hazai, érintett szakmai társaság részt venne. Ezzel sor kerülhetne a kutatásban felmerült anomáliák feloldására, a gyakorlati megvalósíthatóság figyelembevételével.

Anyagi támogatás: A vizsgálat lefolytatását a Nestlé Hungária Kft. és a Numil Kft. finanszírozta, ugyanakkor a közlemény megírása anyagi támogatásban nem részesült.
Szerzői munkamegosztás: K. J., B. K. K.: A vizsgálat tervezése és lefolytatása. Sz. Zs., E.-S. A., R. L. B.: Irodalomkutatás. B. L.: Statisztikai elemzések. E.-S. A., B. K. K., Sz. Zs., K. J., R. L. B.: Az eredmények interpretációja. E.-S. A., B. K. K., Sz. Zs., R. L. B.: A kézirat megszövegezése. A cikk végleges változatát valamennyi szerző elolvasta és jóváhagyta.

Érdekeltségek: A szerzőknek nincsenek érdekeltségeik.

\section{Irodalom}

[1] Kimokoti RW, Millen BE. Nutrition for the prevention of chronic diseases. Med Clin North Am. 2016; 100: 1185-1198.

[2] Chizuru N, Ricardo U, Shiriki K, et al. The Joint WHO/FAO Expert Consultation on diet, nutrition and the prevention of chronic diseases: process, product and policy implications. Public Health Nutr. 2004; $7:$ 245-250.

[3] Brennan P, Perola M, Jan van Ommen G, et al. Chronic disease research in Europe and the need for integrated population $\mathrm{co}^{-}$ horts. Eur J Epidemiol. 2017; 32: 741-749.

[4] Gluckman PD, Hanson MA, Cooper C, et al. Effect of in utero and early-life conditions on adult health and disease. N Engl J Med. 2008; 359: 61-73.

[5] Barker DJ. In utero programming of chronic disease. Clin Sci (Lond). 1998; 95: 115-128.

[6] Osmond C, Barker DJ, Winter PD, et al. Early growth and death from cardiovascular disease in women. BMJ 1993; 307: 15191524 .

[7] Hales CN, Barker DJ. Type 2 (non-insulin-dependent) diabetes mellitus: the thrifty phenotype hypothesis. Diabetologia 1992; 35: 595-601.

[8] Cooper C, Fall C, Egger P, et al. Growth in infancy and bone mass in later life. Ann Rheum Dis. 1997; 56: 17-21.

[9] Rich-Edwards JW, Stampfer MJ, Manson JE, et al. Birth weight and risk of cardiovascular disease in a cohort of women followed up since 1976. BMJ 1997; 315: 396-400.

[10] Charalambous M, da Rocha ST, Ferguson-Smith AC. Genomic imprinting, growth control and the allocation of nutritional resources: consequences for postnatal life. Curr Opin Endocrinol Diabetes Obes. 2007; 14: 3-12.

[11] Dos Santos Silva I, De Stavola BL, Hardy RJ, et al. Is the association of birth weight with premenopausal breast cancer risk mediated through childhood growth? Br J Cancer 2004; 91: 519-524.

[12] Koletzko B, Brands B, Poston L, et al. Early nutrition program ming of long term health. Proc Nutr Soc. 2012; 71: 371-378.

[13] Schellong K, Schulz S, Harder T, et al. Birth weight and longterm overweight risk: systematic review and a meta-analysis including 643,902 persons from 66 studies and 26 countries globally. PLoS ONE 2012; 7: e47776.

[14] Mühlhäusler BS, Adam CL, McMillen IC. Maternal nutrition and the programming of obesity: the brain. Organogenesis 2008; 4: 144-152.

[15] Wu G, Imhoff-Kunsch B, Girard AW. Biological mechanisms for nutritional regulation of maternal health and fetal development. Paediatr Perinat Epidemiol. 2012; 26(Suppl 1): 4-26.

[16] Socha P, Grote V, Gruszfeld D, et al. Milk protein intake, the metabolic-endocrine response, and growth in infancy: data from a randomized clinical trial. Am J Clin Nutr. 2011; 94: 1776S1784S.

[17] Scrimshaw SN. Malnutrition, brain development, learning, and behavior. Nutr Res. 1998; 18: 351-379.

[18] Koletzko B, von Kries R, Closa-Monasterolo R, et al. Can infant feeding choices modulate later obesity risk? Am J Clin Nutr. 2009; 89: 1502S-1508S. 
[19] Embleton ND, Cooke RJ. Protein requirements in preterm infants: effect of different levels of protein intake on growth and body composition. Pediat Res. 2005; 58: 855-860.

[20] Weber M, Grote V, Closa-Monasterolo R, et al. Lower protein content in infant formula reduces BMI and obesity risk at school age: follow-up of a randomized trial. Am J Clin Nutr. 2014; 99: 1041-1051.

[21] Cole TJ, Flegal KM, Nicholls D, et al. Body mass index cut offs to define thinness in children and adolescents: international survey. BMJ 2007; 335: 194.

[22] Joubert K, Ujhelyi G. Growth and nutrition assessment in infants, children and adolescents (BMI) program. [Növekedés és a tápláltsági állapot értékelése csecsemő-, gyermek- és serdülökorban (BMI) program.] Available from: https://mave.hu/uploads/file/BMI/Nov.taplaltsag-BMI-85.P.gyakorlati_utmutato. ppt [accessed: October 6, 2019].

[23] Cole TJ, Bellizzi MC, Flegal KM, et al. Establishing a standard definition for child overweight and obesity worldwide: international survey. BMJ 2000; 320: 1240-1243.

[24] Cameron N. Body mass index cut offs to define thinness in children and adolescents: international survey. BMJ 2007; 335: 166-167.

[25] Fleddermann M, Demmelmair H, Grote V, et al. Infant formula composition affects energetic efficiency for growth: the BeMIM study, a randomized controlled trial. Clin Nutr. 2014; 33: 588595.

[26] EFSA NDA Panel (EFSA Panel on Dietetic Products, Nutrition and Allergies). Scientific opinion on dietary reference values for phosphorus. EFSA Journal 2015; 13: 4185.

[27] Takács I, Benkő I, Toldy E, et al. Domestic consensus on the role of vitamin $\mathrm{D}$ in disease prevention and treatment. [Hazai konszenzus a D-vitamin szerepéről a betegségek megelőzésében és kezelésében.] Orv Hetil. 2012; 153: 5-26. [Hungarian]
[28] Langley-Evans SC. Nutrition in early life and the programming of adult disease: a review. J Hum Nutr Diet. 2015; 28: 1-14.

[29] Biró L, Szabó L. Complex nutritional examination of 1-3-yearold children. [1-3 éves gyermekek komplex táplálkozási vizsgálata.] Gyermekgyógyászat 2011; 62: 80-85. [Hungarian]

[30] Kiss-Tóth B. The relationship between the nutritional habits of Hungarian children and adults according to the surveys. [A magyar gyermekek és felnőttek táplálkozási szokásainak összefüggései a felmérések tükrében.] Új Diéta 2015; 24(5): 2-4. [Hungarian]

[31] World Health Organization. Report of a Joint WHO/FAO/ UNU Expert Consultation. Protein and amino acid requirements in human nutrition, 2007. WHO, Technical Report Series 935, Geneva. Available from: https://apps.who.int/iris/bitstream/handle/10665/43411/WHO_TRS_935_eng.pdf;jsess ionid $=7293079636537 \mathrm{FAA3BE} 27687025 \mathrm{~B} 728 \mathrm{E}$ ? sequence $=1$ [accessed: October 6. 2019].

[32] EFSA NDA Panel (EFSA Panel on Dietetic Products, Nutrition and Allergies). Scientific opinion on nutrient requirements and dietary intakes of infants and young children in the European Union. EFSA Journal 2013; 11: 340.

[33] Kiss-Tóth B. Assessment of nutrition and physical activity of four-to-ten-year-old children - Part 2. [Négy-tíz éves gyermekek táplálkozásának és fizikai aktivitásának felmérése - 2. rész.] Új Diéta 2014; 23(5): 5-7. [Hungarian]

[34] Szúcs Zs, Pálfi E, Badacsonyiné Kassai K. Nutrition habits of domestic children in the context of a comparative analysis. [A hazai gyermekek táplálkozási szokásai egy összehasonlító elemzés tükrében.] Új Diéta 2019; 28(füzet): 2-5. [Hungarian]

(Raposa L. Bence dr., Pécs, Pollack M. u. 5., 7633 e-mail: raposa.bence@gmail.com; bence.raposa@etk.pte.hu)

\section{A rendezvények és kongresszusok híranyagának leadása}

a lap megjelenése előtt legalább 40 nappal lehetséges, a 6 hetes nyomdai átfutás miatt. Kérjük megrendelőink szíves megértését.

A híranyagokat a következő címre kérjük:

Orvosi Hetilap titkársága: edit.budai@akademiai.hu

Akadémiai Kiadó Zrt.

A cikk a Creative Commons Attribution 4.0 International License (https://creativecommons.org/licenses/by/4.0/) feltételei szerint publikált Open Access közlemény, melynek szellemében a cikk bármilyen médiumban szabadon felhasználható, megosztható és újraközölhető, feltéve, hogy az eredeti szerző és a közlés helye, illetve a CC License linkje és az esetlegesen végrehajtott módosítások feltüntetésre kerülnek. (SID_1) 